\title{
Effectiveness of Bemiparin Sodium for Preventing Pregnancy Loss in Patients with MTHFR C677T Mutation and Habitual Abortus
}

\author{
Davut Guven', Kadir Bakay2 ${ }^{*}$, Idris Kocak ${ }^{1}$, Ayse Ozdemir ${ }^{1}$ \\ ${ }^{1}$ Department of Obstetrics and Gynecology, 19 Mayıs University School of Medicine, Samsun, Turkey \\ ${ }^{2}$ Department of Obstetrics and Gynecology, Private Hospital, Istanbul, Turkey \\ Email: ${ }^{*}$ drkadirbakay@gmail.com
}

Received 22 August 2014; revised 20 September 2014; accepted 15 October 2014

Copyright @ 2014 by authors and Scientific Research Publishing Inc.

This work is licensed under the Creative Commons Attribution International License (CC BY).

http://creativecommons.org/licenses/by/4.0/

c) (i) Open Access

\begin{abstract}
Objective: In this study the purpose is to evaluate the effectiveness of daily bemiparin sodium injection in preventing early pregnancy loss and in achieving live births in pregnant patients, not ahead of 6th week, who are diagnosed with habitual abortion in a case-controlled randomized prospective study. Study Design: In this prospective study, 120 pregnant patients not ahead of 6th week and aged between 21 - 36 and diagnosed with habitual abortion between April 2011 and April 2012 in our clinic were included. Habitual abortion diagnosis criteria was based on patient history of three or more miscarriages before the 20th week and a genetically documented homozygote or heterozygote mutation of the methylenetetrahydrofolate Reductase gene. Results: The rate and the number of live births in the study group was $60(93.75 \%)$ and statistically higher than the control group $32(57.14 \%)$. The difference was found to be statistically significant $(p=0.001)$. The rate and the number of abortions in the control group was $24(42.85 \%)$ and statistically higher than the study group $4(6.25 \%)$. The difference was found to be statistically significant $(\mathrm{p}=$ 0.001). Conclusion: In order to maintain a healthy pregnancy an effective uteroplacental circulation is a must and any defects in haemostasis mechanisms may have an adverse influence. A few non-randomized studies comparing pregnancy results of low dose salycilic acid and low molecular weight heparin usage in patients also show that prophylaxis might be beneficial.
\end{abstract}

\section{Keywords}

Habitual, Abortion, MTHFR, Bemiparin, LMWH

\footnotetext{
${ }^{*}$ Corresponding author.
}

How to cite this paper: Guven, D., Bakay, K., Kocak, I. and Ozdemir, A. (2014) Effectiveness of Bemiparin Sodium for Preventing Pregnancy Loss in Patients with MTHFR C677T Mutation and Habitual Abortus. Open Journal of Obstetrics and Gynecology, 4, 930-934. http://dx.doi.org/10.4236/ojog.2014.415131 


\section{Introduction}

Habitual abortus is described as miscarriage of three or more fetuses before the 20th week of pregnancy and is approximately comprised of $1 \%-5 \%$ of all pregnancies [1] [2]. Genetics, endocrine, anatomic, immunologic and infectious problems can be listed in etiology [1] [3] [4]. Among genetic factors, Methylenetetrahydrofolate reductase (MTHFR) gene C677T and A1298C single nucleotide polymorphisms with plasminogen activator inhibitor type-1 (PAI-1) gene 4G/5G polymorphism are considered as risk factors responsible for recurrent pregnancy loss (RPL).

MTHFR is the rate-limiting enzyme in the methyl cycle, and it is encoded by the MTHFR gene [5]. MTHFR catalyzes the conversion of 5,10-methylenetetrahydrofolate to 5-methyltetrahydrofolate, a cosubstrate for the remethylation of homocysteine to methionine.

Homocysteine is an aminoacid synthesised during the methionine metabolism pathway. It is either catabolized along the transsulphuration pathway by cystathionine beta synthase or reverted to methionine via the remethylation pathway by MTHFR [6]. Defects in both pathways result in homocysteine increase which is known to be an independent risk factor for venous thromboembolism (VTE) and atherosclerosis [6]. The reason of polymorphism is either an otosomal dominant defect in cystathionine beta synthase $(0.3 \%-1.4 \%$ of the population) or more commonly (6\% - 12\% of caucasians) an autosomal recessive homozygocity in C677T MTHFR mutation [7].

The prevalence of MTHFR gene mutation in patients with recurrent abortions was found to be statistically higher than patients with anembryonic pregnancies hence supporting the evidence of the role of hypercoagulability and abnormal utero-placental vasculature resulting in RPL [8].

Evidence of treatment options concerning patients with RPL and hereditary thrombophilia is usually comprised of low molecular weight heparin (LMWH) admission on small study series. When compared with unfractioned heparin, LMWH has many advantages including a longer half-life, beter anti-coagulative response and the ease of daily injections along with much lower risk for osteoporosis and heparin induced thrombocytopenia [9]. In a study, 83 pregnancies were achieved among 93 patients diagnosed with habitual abortus who were treated with enoxaparin [10].

In another study, $20 \mathrm{mg}$ of daily enoxaparin usage resulted in $80 \%$ conception and $81 \%$ live birth rates [11]. In another study by Brenner et al., 40 - 80 mg of daily enoxaparin usage resulted in 46 live births out of 61 patients (75\%) [12].

In the present prospective randomized case controlled study the purpose is to evaluate the effectiveness of daily bemiparin sodium injection in preventing early pregnancy loss and in achieving live births in pregnant patients, not ahead of 6th week, who are diagnosed with habitual abortus.

\section{Material and Methods}

In this case controlled randomized clinical prospective study, habitual abortus diagnosis criteria was based on patient history of three or more miscarriages before the 20th week and a genetically documented homozygote or heterozygote mutation of the MTHFR 677 gene.

Patient selection criteria required regular ovulatory mensturations, normal hysterosalphingography (HSG) results with bilateral open tubal passage and a normal sperm analysis to also exclude the male factor.

All other known causes that may result in RPL including those with previous ovarian surgery, endocrine disorders (thyroid disfunctions, hyperprolactinema, polycystic ovarian syndrome), obese patients (body mass index above 30) and all uterine anomalies were omitted in order to obtain an objective comparison concerning LMWH treatment in RPL.

120 pregnant patients not ahead of 6th week and aged between 21 - 36 and diagnosed with habitual abortus between April 2011 and April 2012 were included in the study.

Venous blood of 2 cc were obtained in test tubes containing ethylenediaminetetraacetic acid (EDTA) from all patients with a history of RPL and stored in special containers at +4 degrees celsius, afterwards all stored samples were studied using real-time polymerase chain reaction (PCR) method to obtain DNA for the diagnosis of MTHFR 677 gene mutation.

All data were recorded in specific study forms and computer assigned randomization depending on odd/even number sequence at admittance for receiving or omitting bemiparin sodium injection prophylaxis was performed. 
Study was based on comparing the effectiveness of daily bemiparin sodium injection in preventing early pregnancy loss and in achieving live births in pregnant patients in the first trimester who are diagnosed with habitual abortus according to the criteria described above.

Daily sub-cutaneous injections of 3500 IU bemiparin sodium was administered to 64 patients along with daily oral low dose salycilic acid (100 mg) forming the study group while the remaining 56 received $100 \mathrm{mg}$ daily oral salycilic acid forming the control group.

Chi-square test was used to evaluate the data obtained in the study. Results were evaluated in a $95 \%$ safety zone and a probability (p) value lower than 0.05 was considered to be statistically significant.

The study was subject to ethics committee approval of the institution within which the work was undertaken.

As an ethical precatuion and to maintain a statistical equilibrium low dose $(100 \mathrm{mg})$ salycilic acid was given to both groups.

All patients were required to fill and sign a specific informed consent form detailing the study and the risks involved.

\section{Results}

Forty-six patients in the study group (71.87\%) and 36 patients in the control group (64.28\%) had heterozygote MTHFR C677T mutation (Table 1).

Eighteen patients in the study group (28.12\%) and 20 patients in the control group (35.71\%) had homozygote MTHFR C677T mutation (Table 1).

The rate and the number of live births in the study group was 60 (93.75\%) and statistically higher than the control group $32(57.14 \%)$. The difference was found to be statistically significant $(\mathrm{p}<0.05)$ (Table 2$)$. The rate and the number of abortions in the control group was 24 (42.85\%) and statistically higher than the study group 4 (6.25\%). The difference was found to be statistically significant $(\mathrm{p}<0.05)$ (Table 2).

\section{Discussion}

In order to maintain a healthy pregnancy an effective uteroplacental circulation is a must and any defects in haemostasis mechanisms may have an adverse influence. In that regard, factors causing maternal thrombophilia such as Factor V Leiden, MTHFR C677T mutation, Protrombin G20210A, Protein C, Protein S and Antitrombin III defects are especially significant in obstetrics, emphasizing the fact that a defective uteroplacental circulation is an important factor in fetal demise [13] [14].

While thrombophilia cannot be blamed solely for recurrent pregnancy loss, anti-coagulative treatment, especially with LMWH, has been shown to have positive effects in preventing early pregnancy loss and to achieve live births in patients with RPL or hereditary thrombophilia and although this is still a subject of debate, Heparin/LMWH treatment can be considered to be an effective method in preventing early pregnancy loss while benefiting from its anti-coagulative effects in thrombophilia patients [15] [16].

Table 1. Distribution of genetical analysis.

\begin{tabular}{ccc}
\hline & Study Group (Bemiparin +) & Control Group (Bemiparin -) \\
\hline MTHFR C677T Heterozygote Mutation & $46(71.87 \%)$ & $36(64.28 \%)$ \\
MTHFR C677T Homozygote Mutation & $18(28.12 \%)$ & $20(35.71 \%)$ \\
Total & 64 & 56 \\
\hline
\end{tabular}

Table 2. Chi-Square test comparing the data between two groups.

\begin{tabular}{cccc} 
& Study Group (Bemiparin +$)$ & Control Group (Bemiparin - ) & p \\
\hline Live Birth & $60(93.75 \%)$ & $32(57.14 \%)$ & $0.001^{* *}$ \\
Still Birth & 0 & 0 & $0.001^{* *}$ \\
Abortion & $4(6.25 \%)$ & $24(42.85 \%)$ & \\
Total & 64 & 56 & \\
\hline
\end{tabular}

Chi-Square Test: ${ }^{* *} \mathrm{p}<0.05$. 
A few non-randomized studies comparing pregnancy results of low dose salycilic acid and LMWH usage in RPL patients also show that prophylaxis might be beneficial [11] [17]. Gris et al. have found out, in randomized studies, that when comparing the efficacy of LMWH (in 40 patients) versus low dose salycilic acid (in 40 patients) for achieving live births out of a total of 160 patients diagnosed with RPL, LMWH usage had significantly higher rates of live birth ( $86 \%$ vs $29 \%$ respectively) [18].

\section{Conclusions}

Apparently more studies with a much larger scale are required but our results were in similar range with these studies. Daily administration of bemiparin sodium 3500 IU was able to prevent early pregnancy loss in patients diagnosed with habitual abortion while also increasing live birth rates [19] [20].

There is still not a solidified treatment algorithm available yet and although the debate is on LMWH usage and its dosing to prevent abortions in RPL patients, according to our study results this might be an effective treatment option that should be considered primarily in patients with a history of recurrent abortions but then again more prospective randomized studies including larger groups are still needed to support this argument.

\section{Acknowledgements}

None.

\section{Conflicts of Interest}

Authors state there are no conflicts of interest, financial or otherwise.

\section{References}

[1] Alataş, E. (2004) Tekrarlayan gebelik kayıplarında tanı ve tedavinin yönlendirilmesi. TJD Uzmanlık Sonrası Eğitim Dergisi, 6, 19-25.

[2] Tepeli, E., Müslümanoğlu, H.M. and Uludağ, A. (2007) Eskişehir ilinde idiyopatik tekrarlayan gebelik kayıpları ile metilentetrahidrofolat redüktaz (MTHFR) C677T ve A1298C polimorfizmleri arasındaki ilişki. Osmangazi Tip Dergisi, 29, 1-11.

[3] Oral, D., Alp, M.N. and Budak, T. (2006) Ailesel Resiprokal Translokasyon Olgusu ve Tekrarlayan Düşükler. Dicle Tip Dergisi, 33, 182-184.

[4] Balcı, A., Yirmibeş, M. and Bal, F. (1996) Ailesel Resiprokal Translokasyon Olgusu ve Tekrarlayan Düşükler. Perinatoloji Dergisi, 4, 218-219.

[5] Goyette, P., Sumner, J.S., Milos, R., Duncan, A.M., Rosenblatt, D.S., Matthews, R.G. and Rozen, R. (1994) Human Methylenetetrahydrofolate Reductase: Isolation of cDNA, Mapping and Mutation İdentification. Nature Genetics, 7, 195-200. http://dx.doi.org/10.1038/ng0694-195

[6] Ueland, P., Refsum, H., Stabler, S., et al. (1993) Total Homocysteine in Plasma or Serum: Methods and Clinical Applications. Clinical Chemistry, 39, 1764-1779.

[7] Ray, J.G. and Laskin, C.A. (1999) Folic Acid and Homocyst(e)ine Metabolic Defects and the Risk of Placental Abruption, Pre-Eclampsia and Spontaneous Pregnancy Loss. Placenta, 20, 519-529. http://dx.doi.org/10.1053/plac.1999.0417

[8] Lissak, A., Sharon, A., Fruchter, O., et al. (1999) Polymorphism for Mutation of Cytosine to Thymine at Location 677 in the Methylenetetrahydrofolate Reductase Gene Is Associated with Recurrent Early Fetal Loss. American Journal of Obstetrics \& Gynecology, 181, 126-130. http://dx.doi.org/10.1016/S0002-9378(99)70447-3

[9] Garcia, D.A., Baglin, T.P., Weitz, J.I. and Samama, M.M. (2012) Parenteral Anticoagulants Antithrombotic Therapy and Prevention of Thrombosis, 9th ed: American College of Chest Physicians Evidence-Based Clinical Practice Guidelines. Chest, 141, e24S-e43S,

[10] Sanson, B., Lensing, A., Prins, M., et al. (1999) Safety of Low-Molecularweight Heparin in 82 Pregnancy. Thrombosis and Haemostasis, 81, 668-672.

[11] Gris, J., Neveu, S., Tailland, M., et al. (1995) Use of Low-Molecular Weight Heparin (Enoxaparin) or of a Phenformin-Like Substance (Moroxydine Chloride) in Primary Early Recurrent Aborters with an İmpaired Fibrinolyitic Capacity. Thrombosis and Haemostasis, 73, 362-367.

[12] Brenner, B., Hoffman, R., Blumenfeld, Z., et al. (2000) Gestational Outcome in Thrombophilic Women with Recurrent Pregnancy Loss Treated by Enoxaparin. Thrombosis and Haemostasis, 83, 693-697. 
[13] Preston, F.E., Rosendaal, F.R., Walker, I.D., Briet, E., Berntorp, E., Conrad, J., et al. (1996) Increased Fetal Loss in Women with Heritable Thrombophilia. The Lancet, 348, 913-916. http://dx.doi.org/10.1016/S0140-6736(96)04125-6

[14] Brigden, M.L. (1997) The Hypercoagulable State, Who, How and When to Test and Treatment. Postgraduate Medicine, 101, 5249-5268. http://dx.doi.org/10.3810/pgm.1997.05.252

[15] Dendrinos, S., Makrakis, E., Botsis, D., Chassiakos, D., Baka, S., Creatsas, G., et al. (2005) A Study of Pregnancy Loss in 352 Women with Recurrent Miscarriages. Archives of Gynecology and Obstetrics, 271, 253-259. http://dx.doi.org/10.1007/s00404-004-0607-0

[16] Li, T.-C., Iqbal, T., Anstie, B., et al. (2002) An Analysis of the Pattern of Pregnancy Loss in Women with Recurrent Miscarriage. Fertility and Sterility, 78, 1100-1106. http://dx.doi.org/10.1016/S0015-0282(02)04207-3

[17] Paidas, M.J., Ku, D.H., Arkel, Y.S., et al. (2004) Screening and Management of Inherited Thrombophilias in the Setting of Adverse Pregnancy Outcome. Clinics in Perinatology, 31, 783-805. http://dx.doi.org/10.1016/j.clp.2004.07.002

[18] Gris, J.C., Mercier, E., Quere, I., Lavigne-Lissalde, G., Cochery-Nouvellon, E., Hoffet, M., et al. (2004) Low Molecular Weight Heparin versus Low-Dose Aspirin in Women with One Fetal Loss and a Constitutional Thrombophilic Disorder. Blood, 103, 3695-3699. http://dx.doi.org/10.1182/blood-2003-12-4250

[19] Sharif, K.W. and Ghunaim, S. (2010) Management of 273 Cases of Recurrent İmplantation Failure: Results of a Combined Evidence-Based Protocol. Reproductive BioMedicine Online, 21, 373-380. http://dx.doi.org/10.1016/j.rbmo.2010.03.028

[20] Alalaf, S. (2012) Bemiparin versus Low Dose Aspirin for Management of Early Pregnancy Loss Due to Antiphospholipid Antibody Syndrome. Archives of Gynecology and Obstetrics, 285, 641-647. http://dx.doi.org/10.1007/s00404-011-2055-y 
Scientific Research Publishing (SCIRP) is one of the largest Open Access journal publishers. It is currently publishing more than 200 open access, online, peer-reviewed journals covering a wide range of academic disciplines. SCIRP serves the worldwide academic communities and contributes to the progress and application of science with its publication.

Other selected journals from SCIRP are listed as below. Submit your manuscript to us via either submit@scirp.org or Online Submission Portal.
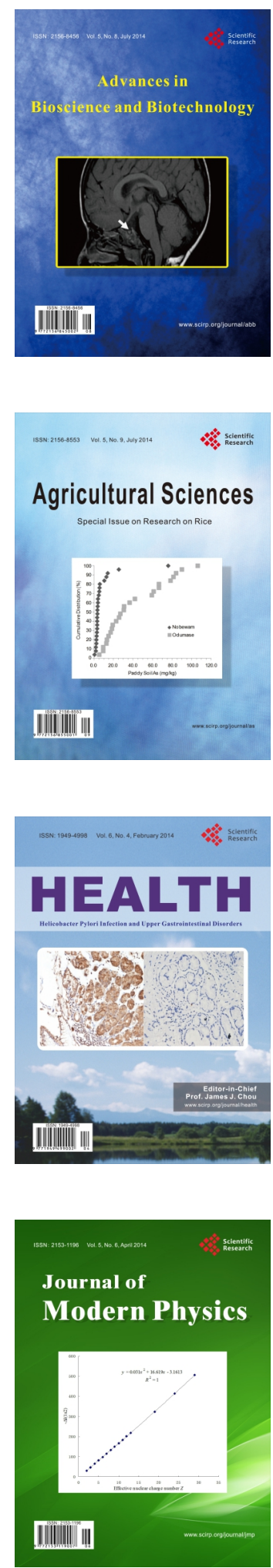
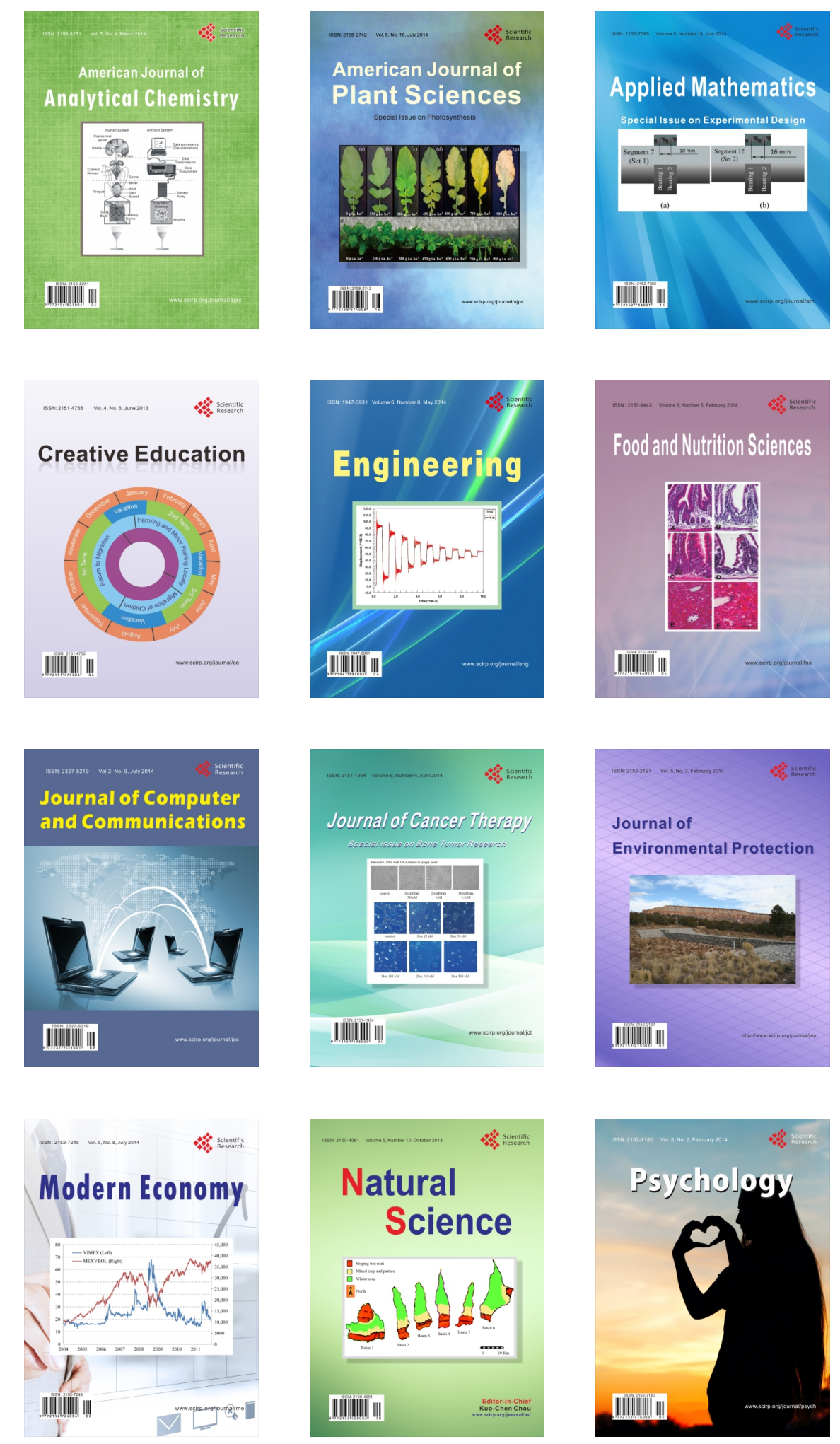